\title{
特集 「カテーテル治療全盛期の心臟血管外科の目指す方向性」
}

\author{
腹部大動脈瘤に対するステントグラフト内挿術の功罪 \\ 一腹部大動脈瘤に対する適切な治療法の選択一 \\ 前田＼cjkstart英明＼cjkstart田中 正史 \\ 日本大学医学部外科学系心臓血管外科学分野
}

\author{
What is the Best Procedure to Treat Abdominal Aortic Aneurysms: \\ Role of the Endovascular Approach \\ Hideaki MAEDA and Masashi TANAKA \\ Department of Cardiovascular Surgery, Nihon University School of Medicine
}

\begin{abstract}
It is inevitable that patients with abdominal aortic aneurysms (AAA) will face life-threatening crises if they do not undergo surgical treatment.

In 1995, the first synthetic graft implantation for an AAA patient was performed by Dr. Arthur Voorhees. The knitted Dacron ${ }^{\circledR}$ fabric graft, a polyester polymer, was developed by Dr. Michael DeBakey and associates in Houston and has been an almost ideal graft material to this day. From the 1960s to 1990s, Dacron ${ }^{\circledR}$ and Teflon ${ }^{\circledR}$ grafts have been implanted in AAA patients with a 95\% success rate. In 1991, Parodi reported the first successful endovascular AAA repair. The stent graft system is an innovative device designed to be a minimally-invasive treatment option for high risk AAA patients. In the 2000s, endovascular aneurysm repair (EVAR) has been developed as a standard procedure for AAA. Some randomized controlled trials have reported that EVAR had an early survival advantage compared with open repair, however, in long-term outcomes, up to 10 years, there were no advantages of EVAR for aneurysm-related and total mortality compared with open repair. We evaluated the long-term survival and aneurysm related complications for patients who underwent EVAR in our institute.

Key words: abdominal aortic aneurysm (AAA), endovascular aneurysm repair (EVAR), complication, longterm outcomes 腹部大動脈瘤 (AAA), ステントグラフト内挿術 (EVAR), 合併症, 長期予後
\end{abstract}

(J. Nihon Univ. Med. Ass., 2017; 76 (3): 139-142)

近代外科は 20 世紀前半に確立されたが，大動脈瘤外 科手術の歴史は代用血管の開発の必要性から遅れ，よ うく 1951 年腹部大動脈瘤に対する同種血管移植成 功がフランスのDubostらにより報告された。その後 Houstonの M.E. DeBakey は自ら開発した knitted Dacron （メリアス織りポリエステル）人工血管を用いて 1,000 例の移植を行い, $90 \%$ の生存率を得る結果を報告 ${ }^{1,2)}$, これがきっかけで 1960 年 knitted Dacron 人工血管が商 品化され，1980 年，1990 年代には米国で死亡率 4-5\% と安定した成績が得られ，多くの患者が恩恵を受けた。 しかし，虚血性心疾患，脳血管疾患合併症等ハイリス ク患者が多く存在するこの分野では，低侵襲手術の開 発が望まれていた。1991 年アルゼンチンの血管外科医 Parodi によるステントグラフト内挿術の臨床成功は画 期的な出来事で，以降この分野の術式を根底から変え るものとなった ${ }^{3)}$ 。すなわち，血管拡張に用いるステン トとDacron（平織りポリエステル）人工血管を組み合 わせて作製したステントグラフトを腸骨動脈から経カ テーテル的に大動脈に送り込み, 病変部でステントグ ラフトを大動脈内に内挿する手技が報告された。1997 年ヨーロッパEMEA，1999 年米国 FDA で企業製ステ
ントグラフトが承認され，その黎明期から現在まで 16 のステントグラフト機器が開発承認されたが, わが国 では欧米からはるかに遅れ 2007 年 4 月, ようやくポ リエステル人工血管とステンレス製 Zステントを組み 合わせた Cook 社製 Zenith，続いて, ePTFE (expanded polytetrafluoroethylene) 人工血管と nitinol ステントを組み 合わせた GoreTex 社製 Excluder，2008 年には Endologic 社の Power Link, Medtronic 社製 Endurant, Lombert 社 製 Aorfix の 5 企業製ステントグラフトシステムが現在ま でに薬事承認，保険償還され，ステントグラフト実施委 員会の管理のもとに実施施設基準を満たした施設，実施 医有資格者でのみ施行可能となっている（図 1).

\section{実施施設と実施医認定}

10 関連学会で構成されたステントグラフト実施基準 管理委員会 (委員長：日本血管外科学会理事長 古森公 浩）が実施施設の認定, 実施, 指導医の資格認定を行 い, 医師の技術水準と IFU (instruction for use) の厳守を 徹底したため, 欧米にみられた，黎明期の混乱状態を経 験することなく, 後発ながら, 欧米を淩駕する成績を得 ている。 2007 年 4 月保険償還から約 1 年後の 2008 年 7 
2006年 : Zenith (COOK JAPAN)

2007年：ゴア Excluder（日本ゴア）

2008年 : Powerlink（コスモテック）

2010年: Zenith Flex (COOK JAPAN)

2010年：TALENT（メドトロニック）

2011 年 : Endurant（メドトロニック）

2012年 : Endurant II (メドトロニック)

2013 年 : Powerlink Intuitrak Delivery

System（コスモテック）

2013年 : ゴア Excluder C3 Delivery

System (日本ゴア)

2014年：Aorfix（メディコスヒラタ)
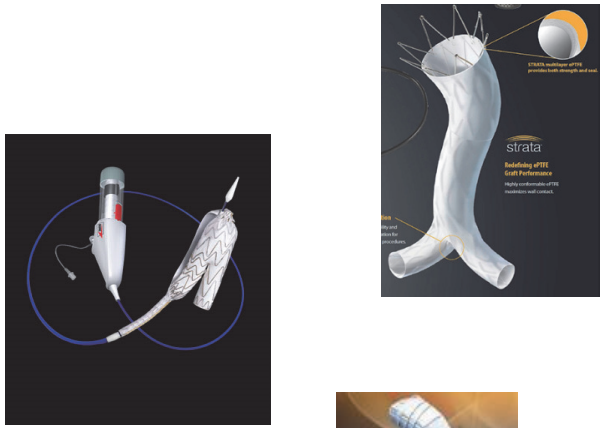

2015年 : AFX (日本ライフライン)
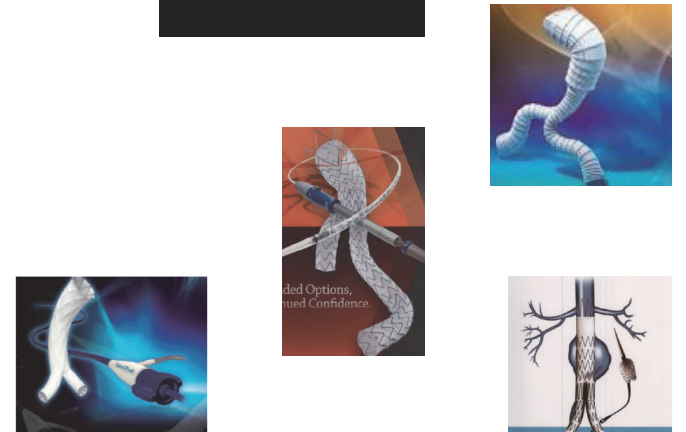

図1 日本国内での認可ステントグラフト

月で 76 施設 622 例が施行され，2015 年 11 月〜2016 年 11 月の 1 年では 4,877 例が施行され, 2016 年 11 月時 点で累積施行数 52,960 例, 施行施設 499 となっている (ステントグラフト実施基準管理委員会)。適応規制の ない米国では 2000 年 28,000 例の AAA 手術例が登録さ れ，EVARは1,680 例 (0.6\%) であったが，2001 年には EVAR 8,760 例 (31.2\%), 2002 年には 10,700 例 (36.2\%), 2003 年 $(41.4 \%)$ と急速に増加傾向にある ${ }^{4}$.

\section{EVAR の適応 (IFU: instruction for use)}

2007 年 4 月, 我国に拉いてステントグラフト内挿術 が保陘償還された際，厚労省は留意事項で “腹部大動脈 用ステントグラフトを使用するに当たっては, 関係学会 の定める当該材料の実施基準に準じること．また，腹部 大動脈瘤の治療を目的とした外科手術を比較的安全に行 うことが可能な患者に対しては，外科手術を第一選択と して治療方法を選択すること，算定に当たっては診療報 酬明細書の摘要欄に外科手術が第一選択とならない旨及 び当該材料による治療が適応となる旨を記載すること” と記載されている。すなわち, 開腹手術が困難で，かつ 解剖学的にステントグラフトの適応条件が満たされてい ることが必要となる。

解剖学的適応は, $1 \mathrm{~mm}$ スライスの MDCT: multidetector row CT あるいは, DSA: 経動脈的血管造影を行い, 以下 の適応基準を検討する（図 2).

1 最大瘤径 $40 \mathrm{~mm}$ 以上

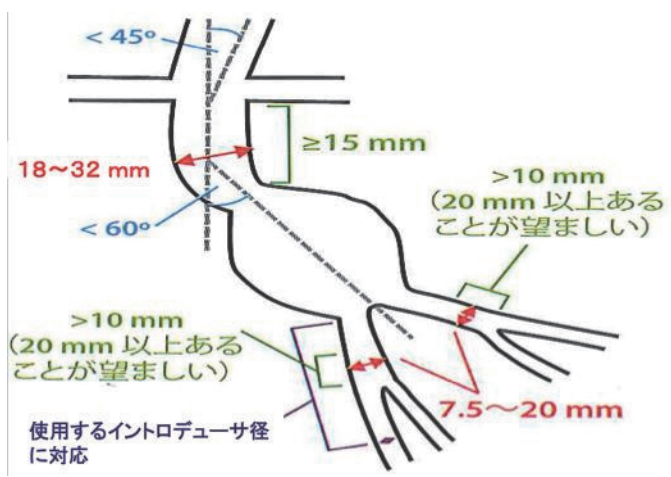

図 2 Zenith (Cook Bloomington, Ind) ガイドから引用

2 proximal neck（腎動脈と瘤までの距離 10-15 mm 以 上, 径 18-30 $\mathrm{mm}$ 以内）

3 proximal neck angle 60 度以下（1 機種のみ 90 度以 下)

4 distal neck（正常総腸骨動脈の長さ） $10 \mathrm{~mm}(20$ $\mathrm{mm}$ が望ましい）以上

5 留置部に高度の石灰化, 血栓を有しない

6 access route の狭窄，石灰化，屈曲蛇行がない 麻酔法は, 緊急開腹手術移行を考慮し，全身麻酔下手術 室での施行が望ましいが，局所麻酔でも施行可能であ る. 2017 年 4 月の時点で改良された機器が追加認可を 受け, Endurant IIs が中枢 neck $10 \mathrm{~mm}$ の短い例，中枢屈 曲例，総腸骨動脈 $20 \mathrm{~mm}$ の拡張例， access route 不良例 に対する親水性のカテーテル，Aorfix (Lombert)が中枢 側 90 度高度屈曲に対応している. 


\section{EVAR の早期，遠隔期合併症}

EVAR は低侵襲で，上記解剖学的適応を遵守すれば, 大きな合併症は回避可能である。しかし，現在まで，以 下の合併症の報告があり，本法施行中あるいは経過観察 中は，常に，合併症の発症を考慮する必要がある，特 に，後述の，Type I/III エンドリーク（造影剂の漏れ）は 最終造影で正確な確認を要し，エンドリークを確認した 場合は，即，適切な追加処置が必要である。Type II 工 ンドリークの場合は経過観察可能である ${ }^{12)}$.

\section{術中合併症の発症率 (17-26\%)}

1. ステントグラフト留置不能, 留置部位不適切, 留置 後移動 $(0.5-7 \%)$

2. 動脈損傷

3. エンドリーク $(15 \%)$

ステントグラフト留置後ステントグラフト内腔より 外側で大動脈瘤内に血流が残存する状態

Type I ステントグラフトと宿主大動脈の接合面不 良で起こる場合

Type II 腰動脈, 下腸間膜動脈の逆流血で起こる場 合

Type III ステントグラフト脚接合部から起こる場合 一時性エンドリーク：術後 48 時間以内に消失する 持続性エンドリーク：48 時間以上持続するエンド リーク

4. ステントグラフト狭窄，閉塞 (0.7-10\%)

高度の石灰化，動脈硬化，狭窄，屈曲蛇行が腸骨動 脈に存在する場合，遠隔期にステントグラフトが変 形し，狭窄，閉塞を起こすことがある。

5. 塞栓症 $(0-1.9 \%)$

腸管梗塞，末梢血管微小塞栓症が低頻度ながら報告 がある。

6. 腸管虚血 $(0-3.3 \%)$

ステントグラフトで下腸間膜動脈を閉鎖することに なるが，両側内腸骨動脈が開存していれば，可能性 は極めて低いと考える

7. 術後出血.

access route の外腸骨動脈は後腹膜腔に存在し，ス テントグラフト挿入部あるいはステントグラフト内 挿時に損傷が执こり，後腹膜出血をきたす。

ヨーロッパでは 1999 年から EVAR 症例の登録, 予 後調查が行われ, EUROSTAR と名付けられている. 1999-2004 年登録された 2,846 例中, 術後 1 年以内の 合併症は type II エンドリークが 370 例 13\% と最も高 頻度で，続いて type I, III エンドリークの順となって いる．Type II エンドリークは自然に消失する頻度が高 く，一般に経過観察される。それに対し，type I, III は 瘤破裂につながる危険があるため，再治療が必要となる。
EUROSTAR の報告では，それらに対する再治療は 247 例 $8.7 \%$ であっだ5.

米国多施設調查では，ステントグラフト術中，術後 合併症は Cook Zenith 29\%, GoreTex Excluder 35\% と開 腹手術に比べ高頻度である ${ }^{6,7)}$ ，企業が提示する IFUに 従った厳格な解剖学的適応を見極めなければ，逆に患者 への負担の多い治療になる可能性がある5 . 我国におけ る薬事承認の遅れた原因は，米国に抢ける黎明期の相次 ぐデバイスの市販後認可取り消しという企業側の原因 に加え，医師の厳格な IFU 遵守の不履行，技術的問題 等もあり，高率な合併症の発症が報告されていたため と推測する. EVAR 症例の増加とともに開腹例との比較 検討が行われ，手術死亡率に沶いて開腹 3.8-5.7\% に対 し，EVARは 0.5-2.1\% と開腹術を凌駕している結果が 報告されている ${ }^{8 \sim 10)}$ 、ヨーロッパ多施設調查報告でも, 3 年瘤関連生存率 $98.2 \%$, 瘤径 $<5.5 \mathrm{~cm}$ 群では 3 年生存 率 $99.7 \%$ ，瘤径 $>5.5 \mathrm{~cm}$ 群では $97 \%$ とすばらしい成績 を報告している ${ }^{11)}$. GoreTex Excluder の 5 年市販後調査 でも，破裂率 $0.2 \%$, 再治療率 $5.1 \%$, 手術移行 $0.36 \%$, 30 日死亡率 $0.1 \%$ と製品に改良が加えられ，満足すべき 結果を得ている6)。一方， 2016 年 EVAR vs. open repair の 15 年間の生命予後, 瘤関連死亡をエンドポイントに 見たEVAR1 trial 無作為比較試験では，術後 4 年までは EVAR と開腹群に差は認めなかったが，5 年以降 EVAR に死亡率が高く, 15 年までに 13 例 $(7 \%)$ の破裂例が報 告され，EVARの優位性が認められなくなっている ${ }^{13)}$. また，EVAR 関連合併症による再治療の率が 10-20\% 以 上との報告があり，厳格な IFU 遵守がなければ，手術 への移行，晚期瘤破裂に至る可能性がある ${ }^{14,15)}$.

\section{日大板橋病院症例の検討}

2005 年手作りステントグラフト内揮術を行い, 2007 年 7 月から企業製ステントグラフト実施施設認定を受 け, 2017 年 3 月まで 314 例の企業性ステントグラフト

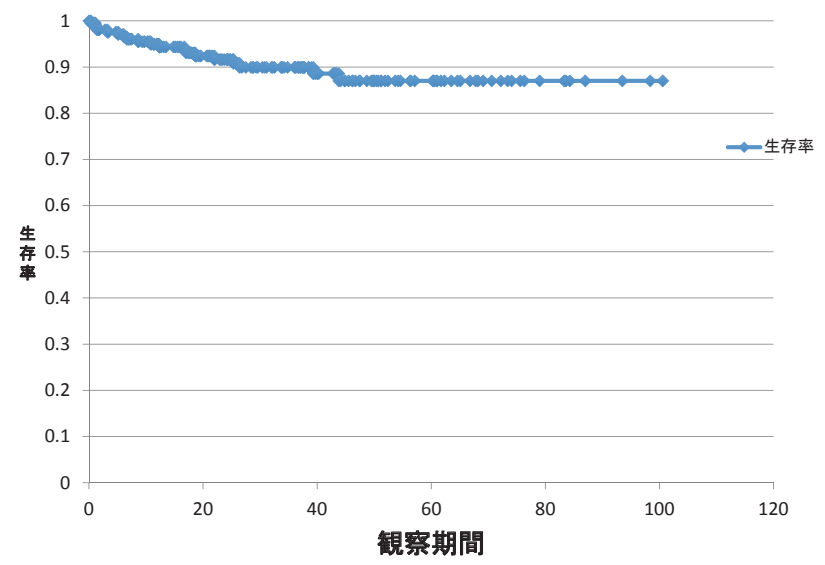

図 3 EVAR 累積生存率（Kaplan-Meier 法） Cumulative survival rates after EVAR 
表 1 Characteristic of AAA patients

\begin{tabular}{llccc}
\hline \multicolumn{1}{c}{ 瘤予後 } & \multicolumn{1}{c}{ 拡大 } & 縮小 & 消失 & \multicolumn{1}{c}{ 変化なし } \\
\hline 年齢 $(\mathrm{y})$ & $76.3 \pm 8.2$ & $75.8 \pm 7.8$ & $75.4 \pm 9.6$ & $75.4 \pm 8.5$ \\
EVAR 時瘤径 $(\mathrm{mm})$ & $54.0 \pm 10.4$ & $54.6 \pm 8.5$ & $46.6 \pm 6.0$ & $56.4 \pm 12.6$
\end{tabular} *

表 2 Re-intervention for aneurysm-related complications

\begin{tabular}{cccc}
\hline 脚閉塞 & 脚逸脱 & 脚狭窄 & graft 損傷 \\
\hline 7 & 3 & 1 & 1 \\
\hline
\end{tabular}

内挿術（腹部 254 例，胸部 60 例）を行った。全例内挿 可能で内挿成功率は $100 \%$ であった。今回 EVAR 術中 術後のステントグラフト関連合併症, 生命予後について 検討した.

対象と方法：EVAR 術後 1 年以上経過した 211 症 例（男性 161 例，女性 50 例 ），平均年齢は $75.3 \pm 8.4$ 歳を対象とした。平均瘤径 $54.2 \pm 8.7 \mathrm{~mm}$, IFU 内 110 例, IFU 外 101 例, IFU 外は腸骨動脈瘤合併, 中枢側, access route 高度屈曲, 中枢 neck 不良であった。

結果：EVAR 術中血管損傷を 2 例認めた。 1 例は緊急 開腹し損傷腸骨動脈部修復， 1 例は access route の損傷 で人工血管置換術を行ったが，ステントグラフト内挿 術は完遂できた。 30 日以内の早期死亡を 2 例認めたが, 急性腎不全と急性呼吸不全が原因でEVAR 関連死は認 めなかった。遠隔期に 18 例の死亡を認め（5 年累積生 存率 $87.0 \%$ ), 瘤関連死亡は 1 例であった（図 3)。瘤径 の予後は（観察期間 1.2-100.6 か月, 平均 24.9 か月）で, 瘤径拡大 26 例 (12.3\%), 消失 27 例 (12.8\%), 縮小 107 例 $(51.2 \%)$, 変化なし $(19.4 \%)$, 追跡不明 9 例であった。 拡大・縮小は手術時に比べ $5 \mathrm{~mm}$ 以上とした。拡大，縮 小, 消失. 変化なし群の各群間において年齢に有意差 は認めず，EVAR 施行時瘤径は拡大群 $54.0 \pm 10.4 \mathrm{~mm}$, 消失群 46.6土6.0 mm と消失群が有意に小径であった. EVAR 関連合併症で再治療を要した症例は 12 例 (5.9\%) で，脚閉塞 7 例，脚逸脱 3 例，Ia エンドリーク 2 例， Ib エンドリーク 1 例，遠隔期（術後 8.5 年）graft 損傷 1 例 であった。再治療後の経過は良好である（表 1 ，表 2 ）。

\section{結 語}

EVAR は低侵襲で超高齢化時代を迎え, 今後益々適応 症例の増加が見込まれる。しかし，EVAR1 trial で報告 されたように，5年を超える遠隔期には瘤関連合併症， 死亡率が開腹手術を上回り，15 年では 7\%の破裂例が あり，未だEVARの手術への優位性が証明されていな い. 今後も, 㛜格な IFU 遵守の上の EVAR 施行が求め られる。

\section{文献}

1) Smith RB III. Presidential address: The foundations of modern aortic surgery. J Vasc Surg 1998; 27: 7-15.

2) 田辺達三。難関とされた動脈瘤手術。外科 $1991 ; \mathbf{6 1}$ : 1167-1169.

3) Parodi JC, Palmaz JC, Barone HD. Transfemoral intraluminal graft implantation for abdominal aortic aneurysms. Ann Vasc Surg 1991; 5: 491-499.

4) Dillavon ED, Muluk SC, Makaroun MS. Improving aneurysm-related outcomes: Nationalwide benefits of endovascular repair. J Vasc Surg 2006; 43: 446-452.

5) Hobo R, Buth J, on behalf of EUROSTAR collaborators. Secondary interventions following endovascular abdominal aortic repair using current endografts. A EUROSTAR report. J Vasc Surg 2006; 43: 896-902.

6) Haider S, Najjar SF, Cho JS, et al. Sac behavior after aneurysm treatment with the Gore Excluder low-permeability aortic endoprosthesis: 12-month comparison to the original Excluder device. J Vasc Surg 2006; 44: 694-700.

7) D'Ellia P, Tyrrell M, Azzaoui R, et al. Zenith abdominal aortic aneurysm endovascular graft: a literature review. $J$ Cardovasc Surg 2009; 50: 165-170.

8) Abbruzzese TA, Kwolek CJ, Brewster DC, et al. Outcomes following endovascular abdominal aortic aneurysm repair (EVAR): an anatomic and device-specific analysis. $J$ Vasc Surg 2008; 48: 19-28.

9) Greenhslgh RM, Beown LC, Kwong GP, et al. Comparison of endovascular aneurysm repair with open repair in patients with abdominal aortic aneurysm (EVAR trial I), 30day operative mortality results:randomized controlled trial. Lancet 2004; 364: 843-848.

10) Prinssen $M$, Verhoeven EL, Buth J, et al. A randomized trial comparing conventional and endovascular repair of abdominal aortic aneurysms. $N$ Engl J Med 2004; 351: $1607-1618$.

11) Leurs LJ, Hobo R, Buth J, on behalf of the EUROSTAR Collaborators. The multicenter experience with a thirdgeneration endovascular device for abdominal aortic aneurysm repair. A report from the EUROSTAR database. $J$ Cardiovasc Surg 2004; 45: 293-300.

12）倉谷 徹. 胸部大動脈瘤の治療一現状と将来一 3 . ステ ントグラフト内挿術（適応，成績，合併症）。日外会誌 2009; 110 (5): 261-265.

13) Patel R, Sweeting MJ, Powell JT, Greenhalgh RM, for the EVAR trial investigators. Endovascular versus open repair of abdominal aortic aneurysmin 15-years' follow-up of the UK endovascular aneurysm repair trial 1 (EVAR trial 1): a randomised controlled trial. Lancet 2016; 388: 2366-2374.

14) Al-Jubouri M, Comerota AJ, Thakur $\mathrm{S}$, et al. Reintervention after EVAR and open surgical repair of AAA: a 15-year experience. Ann Surg 2013; 258 (4): 652-657.

15) Lee K, Tang E, Dubois L, et al. Durability and survival are similar after elective endovascular and open repair of abdominal aortic aneurysms in younger patients. $J$ Vasc Surg 2015; 61: 636-634. 